\title{
Relationship between coronary artery calcification and various biomarkers in type 2 diabetic patients
}

\section{Tip 2 diyabetik hastalarda koroner arter kalsifikasyonu ile biyokimyasal değişkenler arasındaki ilişki}

\author{
Alpaslan Karabulut*, Serhat İçağasığlu, Fettah Acıbucu, Fatih Kılıçlı, Cesur \\ Gümüş, Osman Can Yontar
}

Internal Medicine Clinic (A. Karabulut, MD) Çorum State Hospital, TR-19000 Çorum, Department of Endocrinology and Metabolism (F. Acıbucu, MD, Assist. Prof. F. Kılıçlı, MD) Department of Internal Medicine (Assist. Prof. S. İçağasığlu, MD) Department of Radiology (Assoc. Prof. C. Gümüş, MD) Cumhuriyet University School of Medicine, TR-58140 Sivas, Cardiology Clinic (O. C. Yontar, MD) Sivas Numune Hospital, TR-58040 Sivas

\begin{abstract}
Aim. Cardiovascular disease is the most common made of mortality in type 2 diabetes mellitus. This study investigated the relationship between the presence of calcification in coronary artery and biochemical parameters alone with the classic risk factors of atherosclerosis in patients with type 2 diabetes. Methods. Forty one (27 female and 14 male) patients with type 2 diabetes without symptomatic coronary artery disease (CAD) or previous myocardial infarction and with normal kidney functions were included in the study. Multislice Computerized Tomography (MSCT) was used for coronary artery calcium scoring (CACS). Patients were classifed into two groups as $\mathrm{CACS}=0$ and $\mathrm{CACS}>0$. Results. In $12(29.3 \%)$ patients coronary artery calcification was noted. Waist circumference, systolic blood pressure, total cholesterol, low-density lipoprotein, and triglyceride levels were significantly different between those with (CACS $>0$ ) and without $(\mathrm{CACS}=0)(\mathrm{p}<0.05)$. Conclusion. Coronary artery calcification is related to atherosclerosis in diabetic patients.
\end{abstract}

Keywords: Type 2 diabetes mellitus, atherosclerosis, coronary artery calcification

\section{Özet}

Amaç. Kardiyovasküler hastalık Tip 2 Diabetes Mellitus'ta mortalitenin en sık görülen nedenidir. Bu çalışmada Tip 2 diyabetik hastalarda, koroner arterdeki kalsifikasyon varlığ 1 ile biyokimyasal parametreler ve aterosklerozun klasik risk faktörleri arasındaki ilişki incelendi Yöntemler. Çalışmaya, semptomatik koroner arter hastalı̆̆ı (KAH) yada geçirilmiş miyokard infarktüsü olmayan ve böbrek fonksiyonları normal olan, 41 (27 kadın, 14 erkek) Tip 2 diyabetik hasta alındı. Çok Kesitli Bilgisayarlı Tomografi (ÇKBT) ile koroner arter kalsiyum skorlaması (KAKS) yapıldı. Hastalar KAKS $=0$ ve KAKS $>0$ olarak 2 gruba ayrıldı. Bulgular. $12(\% 29,3)$ hastada koroner arterlerde kalsifikasyon saptandı. Bel çevresi, sistolik kan basıncı, total kolesterol, düşük dansiteli lipoprotein ve trigliserid seviyeleri ile KAKS arasındaki ilişki önemli bulundu $(\mathrm{p}<0,05)$. Sonuç. Diyabetik hastalarda koroner arter kalsifikasyonu aterosklerozla ilişkilidir.

Anahtar sözcükler: Tip 2 diabetes mellitus, ateroskleroz, koroner arter kalsifikasyonu

Geliş tarihi/Received: July 22, 2011; Kabul tarihi/Accepted: March 12, 2012

\section{*Corresponding author:}

Dr. Alpaslan Karabulut, Dahiliye Kliniği, Çorum Devlet Hastanesi, TR-19000 Çorum. E-mail: dralpaslan_78@hotmail.com 


\section{Introduction}

Although diabetes mellitus (DM) is known as a metabolic disease related to carbohydrate metabolism, it is in fact accepted to be a vascular disease due to its close relation with atherosclerosis. Cardiovascular disease is the most significant cause of mortality in Type $2 \mathrm{DM}$ and is responsible from $75 \%$ of the deaths [1]. Even though atherosclerosis affects cerebral and peripheral arteries, the actual cause of death is myocardial infarction (MI). The risk of coronary artery disease (CAD) in patients with Type 2 DM is 2-4 times higher compared with normal population. The risk of developing MI in patients with DM without history of CAD is identical with persons with CAD history and no DM [2]. It would be beneficial to diagnose atherosclerosis before the first MI, and even before the occurrence of CAD symptoms [3]. Calcific deposits in coronary artery are in connection with coronary artery atheroma plaque and are a definite indicator of atherosclerosis. Clinical and histopathologic studies demonstrate a close relationship between the severity of coronary artery disease and coronary artery calcium score (CACS) [4].

In this study, we aimed to investigate whether there is a relationship between traditional risk factors and the coronary calcification.

\section{Materials and method}

This study was conducted in the Internal Medicine Clinic of Cumhuriyet University Healthcare Services Implementation and Research Hospital. Consecutive Type 2 DM patients admitted to the Internal Medicine Clinic were enrolled. All participants were briefed before the study and their consent were obtained for their participation. Patients with diabetic nephropathy, CAD, age younger than 18, malignancy, any acute diseases, infections, pregnancy, and Type 1 DM were excluded from the study. Patients with CAD were eliminated by evaluating their anamneses and electrocardiographies. Remaining 41 type $2 \mathrm{DM}$ cases were included in the study. Medical history of patients was obtained and their physical exams were carried out. During their physical exam, body mass index (BMI) was calculated by individual's body weight divided by the square of his or her height $\left(\mathrm{kg} / \mathrm{m}^{2}\right)$. Waist circumference was also measured. For detecting the presence of hypertension, hypertension and antihypertensive drug use were investigated at the time of anamnesis. Blood pressures were measured according to the recommendations by American Society of Hypertension, following at least a 20 minutes rest in a sitting position, and with mercury sphygmomanometer from the right arm. Since the patients were diabetic, patients with systolic blood pressure equal to or higher than $130 \mathrm{mmHg}$ and diastolic blood pressure equal or higher than $80 \mathrm{mmHg}$, and patients taking antihypertensive drugs at the time were held as hypertensive. Triglycerides (TG), high density cholesterol (HDL), low density cholesterol (LDL), Total cholesterol (TC), calcium, phosphorus, high-sensitive $\mathrm{C}$ reactive protein (hs-CRP), hemoglobin Alc (HbA1c), and parathormone (PTH) values were checked in blood samples drawn after 12 hours of fasting. Laboratory procedures of the study were conducted with enzymatic/GPO-Trinder method by utilizing Syneron system triglyceride kit in Triglyceride, Synchron LX20 autoanalyzer. Total cholesterol was checked with enzymatic method by utilizing Syneron system cholesterol kit in Synchron LX20 autoanalyzer. HDL cholesterol was checked with homogenous calorimetric method by utilizing Syneron System HDL Cholesterol kit in Synchron LX20 autoanalyzer. LDL cholesterol was calculated by Friedwald formula $[\mathrm{LDL}=\mathrm{TC}-(\mathrm{HDL}+\mathrm{TG} / 5)]$. Hs-CRP measurement was conducted with nephelometric method utilizing Beckman-CoulterImage kit in Beckman-Coulter-Image fully automatic device. Microalbumin was found with immunoturbidimetric method by utilizing Syneron system microalbuminuria kit in Synchron LX20 autoanalyzer. Calcium measurement was carried out with ion selective electrode method in Syncihron LX20 autoanalyzer. Phosphorus value was established photometrically with phosphomolybdate method in Syncihron LX20 autoanalyzer. HbA1C measurement was conducted with immunoinhibition method in Synchron LX20 autoanalyzer. Parathormon measurement was carried out with ECLIA 
(electrochemiluminescence immunoassay) method in a Cobas device by utilizing Roche/Hitachi elecsys kit. In order to establish CACS, computerized tomography scans were conducted with Multislice CT (MSCT) (Philips Brilliance 16 slice CT, Holland) device and without contrast agents. All of the scans were carried out with the parameters of $3 \mathrm{~mm}$ slice thickness and $2.4 \mathrm{~mm}$ table movement, $55 \mathrm{~mA}, 120 \mathrm{kV}$, gantry rotation time of $0.5 \mathrm{sec}$ and by calcium scoring algorithm. In the study, the four major coronary arteries, left main coronary artery (LMCA), left circumflex artery (LCX), left anterior descending artery (LAD) and right coronary artery (RCA) were evaluated in terms of calcified lesion presence along the entire lengths of traces. The amount of calcium in coronary arteries was calculated with the help of "AccuImage Workstation" by utilizing Agatston scoring. Based on these scoring, lesions with a CT density higher than $130 \mathrm{HU}$ on an area wider than $1 \mathrm{~mm} 2$ for 2-3 neighboring pixels were evaluated in favor of calcification [5]. Total Agatston score (CACS) was found by adding the scores of calcium in all coronary arteries.

\section{Statistical Analyses}

Data of the study were uploaded to SPSS (ver:14.0) software, and Mann-Whitney U test, Kruskal-Wallis test, Fisher's Exact test and Chi-Square test were applied in their evaluation. The data were shown on tables as mean standart deviation, number and percentage of individuals, and the error level was taken as 0.05 . $\mathrm{P}<0.05$ was accepted as significant.

\section{Results}

Demographic characteristics of the patients (14 male and 27 female) were given in table 1. After calcification scoring of patients by MSCT, patients were classified into two groups as $\mathrm{CACS}=0$ and CACS $>0$. While CACS equaled 0 in 29 patients, it was CACS $>0$ in 12 patients. Various comparisons were carried out between the groups. There was a significant difference between two groups only in following parameters: waist circumference, systolic blood pressure, total cholesterol, TG and LDL cholesterol (Table 2). Although a statistically significant relation was not established between male and female genders and CACS, CACS rate in males was more frequent in males compared with females. $\left(\chi^{2}=1.89 ; \mathrm{p}=0.168\right)$ (Table 3$)$. Retinopathy was observed in 12 patients $(29.3 \%)$ of the entire study population. CACS $=0$ and CACS $>0$ groups were similar in terms of retinopathy (Table 4).

Table 1. Distribution of Type $2 \mathrm{DM}$ individuals based on the measured parameters.

\begin{tabular}{|c|c|c|c|}
\hline Variables & Minimum & Maximum & Median \\
\hline Age(year) & 41 & 64 & 52 \\
\hline BMI $\left(\mathrm{kg} / \mathrm{m}^{2}\right)$ & 21.30 & 41.00 & 30 \\
\hline Waistline (cm) & 74.00 & 130.00 & 97 \\
\hline Diabetes duration (year) & 4.00 & 11.00 & 7 \\
\hline Systolic blood pressure (mmHg) & 100.00 & 180.00 & 132 \\
\hline Diastolic blood pressure (mmHg) & 60.00 & 100.00 & 78 \\
\hline $\mathrm{HbA} 1 \mathrm{c}(\%)$ & 3.80 & 15.53 & 9 \\
\hline Microalbuminuria (mg/day) & 5.25 & 500.00 & 63 \\
\hline Calcium (mg/dL) & 8.40 & 10.30 & 9.4 \\
\hline Phosphorus (mg/dL) & 1.80 & 5.20 & 3.2 \\
\hline Parathyroid hormone (pg/mL) & 12.56 & 130.50 & 46 \\
\hline hs-CRP (mg/L) & 0.20 & 11.80 & 4 \\
\hline Triglyceride $(\mathrm{mg} / \mathrm{dL})$ & 36.00 & 483.00 & 146 \\
\hline Total cholesterol (mg/dL) & 110.00 & 259.00 & 193 \\
\hline LDL cholesterol (mg/dL) & 48.00 & 209.00 & 119 \\
\hline HDL cholesterol (mg /dL) & 21.30 & 82.00 & 9 \\
\hline CACS (Agatston score) & 0.00 & 481.60 & 35 \\
\hline
\end{tabular}

BMI: Body mass index, CACS: Coronary artery calcium score, HDL: High density cholesterol HbA1c: Hemoglobin A1c, hs-CRP: High-sensitive C reactive protein, LDL: Low density cholesterol, PTH: Parathormone 
Table2. Distribution of some demographic and laboratory parameters of the groups.

\begin{tabular}{llll}
\hline Variables & CACS $=\mathbf{0}$ & CACS $>\mathbf{0}$ & Findings \\
\hline BMI $((\mathrm{kg} / \mathrm{sqm})$ & $29.97 \pm 4.23$ & $29.62 \pm 4.50$ & $\mathrm{p}=0.482$ \\
Waist circumference (cm) & $94.44 \pm 10.83$ & $102.66 \pm 11.61$ & $\mathrm{p}=0.049$ \\
$\mathrm{SBP}(\mathrm{mmHg})$ & $127.41 \pm 50.59$ & $141.66 \pm 22.89$ & $\mathrm{p}=0.047$ \\
DBP (mmHg) & $75.17 \pm 10.30$ & $84.16 \pm 13.78$ & $\mathrm{p}=0.064$ \\
Diabetes duration (year) & $7.00 \pm 2.28$ & $6.41 \pm 7.06$ & $\mathrm{p}=0.519$ \\
hs-CRP (mg/L) & $3.67 \pm 3.22$ & $4.71 \pm 4.00$ & $\mathrm{p}=0.586$ \\
Ca (mg/dL) & $9.32 \pm 0.43$ & $9.46 \pm 0.37$ & $\mathrm{p}=0.350$ \\
P (mg/dL) & $3.16 \pm 0.72$ & $3.15 \pm 0.91$ & $\mathrm{p}=0.909$ \\
PTH (pg/mL) & $42.65 \pm 16.88$ & $54.02 \pm 32.04$ & $\mathrm{p}=0.492$ \\
HbA1c (\%) & $8.08 \pm 2.80$ & $9.50 \pm 3.59$ & $\mathrm{p}=0.229$ \\
Total Cholesterol (mg/dL) & $185.27 \pm 34.94$ & $210.91 \pm 45.24$ & $\mathrm{p}=0.032$ \\
LDL (mg/dL) & $109.15 \pm 29.83$ & $141.75 \pm 39.12$ & $\mathrm{p}=0.012$ \\
Tryglicerides (mg/dL) & $134.34 \pm 88.38$ & $166.25 \pm 48.32$ & $\mathrm{p}=0.040$ \\
HDL (mg/dL) & $40.08 \pm 14.04$ & $37.13 \pm 5.72$ & $\mathrm{p}=0.875$ \\
Microalbuminuria (mg/day) & $60.70 \pm 101.58$ & $67.68 \pm 137.04$ & $\mathrm{p}=0.557$ \\
\hline BMI: Body mass index, DBP: Diast
\end{tabular}

BMI: Body mass index, DBP: Diastolic blood pressure, HDL: High density cholesterol HbA1c: Hemoglobin A1c, hs-CRP: High-sensitive C reactive protein, LDL: Low density cholesterol, PTH: Parathormone, SBP: Systolic blood pressure

Table 3. Relation between gender and CACS.

\begin{tabular}{lllll} 
& \multicolumn{2}{c}{ CACS $=\mathbf{0}$} & \multicolumn{2}{c}{ CACS $>\mathbf{0}$} \\
& $\mathbf{n}$ & $\mathbf{\%}$ & $\mathbf{n}$ & $\mathbf{\%}$ \\
\hline Male gender & 8 & 57.1 & 6 & 42.9 \\
Female gender & 21 & 77. & 6 & 22.2 \\
Findings & $\mathrm{x}^{2}=1.89$ & $\mathrm{p}>0.05$ \\
\hline $\mathbf{x}^{\mathbf{2}}$ :Chi-Square Test CACS: Coronary & artery calcium score \\
\hline
\end{tabular}

Table 4. Examination of the groups included in the study in terms of retinopathy.

\begin{tabular}{lll}
\hline CACS & \multicolumn{2}{c}{ Retinopathy } \\
\cline { 2 - 3 } & $\mathbf{n}$ & \% \\
\hline 0 & 8 & 27.6 \\
$>0$ & 4 & 33.4 \\
Total & 12 & 29.3 \\
\hline p: 0.721 & & \\
\hline
\end{tabular}

\section{Discussion}

Diabetes mellitus constitutes a diathesis for atherosclerosis, especially for coronary heart disease. Atherosclerosis may appear in quite early age in diabetic patients. About $75 \%$ of the type 2 diabetes patients die because of cardiovascular diseases [6]. Classic risk factors of atherosclerosis are more prevalent in diabetic cases when compared with normal population. In addition to these classical risk factors like dyslipidemia, hypertension, hyperglycemia, smoking, premature CAD history in the family; non-classical risk factors such as hyperinsulinemia, insulin resistance, endothelium dysfunction, inflammation, and renin-angiotensin system hyperactivation may play a role in the atherosclerosis process in diabetic cases [7].

Presence of calcification in coronary artery is a definite indicator of coronary atherosclerosis. Clinical and histopathological studies that have been conducted so far demonstrated a linear relationship between the amount of calcium accumulated in vessel wall and total atherosclerotic plaque provides valuable information in determining the risk of future cardiovascular disease [8]. In various studies conducted with EBCT and MSCT, CAC was observed to increase in diabetic patients $[9,10]$. In a study that investigated CACS by EBCT, atherosclerotic luminal narrowing and calcification was 
reported to have a correlation and this was confirmed histopathologically in autopsy series of cases as well [11]. In their study, Mielke et al. [12] compared CACS values of type 2 diabetic patients with non-diabetic patients who presented similar risk factors and found that CACS values were higher in type 2 diabetic patients. On the other hand, Khaleeli et al. [13] demonstrated that CAC (coronary artery calcification) prevalence of non-diabetic patients with established CAD and asymptomatic diabetic patients are identical. In another study, type 2 diabetic patients were followed up for CACS during five years. Mortality risk for diabetic patients with any positive value of CACS was higher when compared with non-diabetics and with diabetic patients with CACS $=0$ [14]. These results suggest a relationship between mortality and CACS in diabetic patient group.

It was established in numerous studies that a strong relationship between coronary wall calcification and atherosclerotic CAD exists and that a higher CAD prevalence is present in diabetic patients. In addition, asymptomatic diabetic patients have similar CACS values and mortality rates with non-diabetic CAD patients [12-14]. There appears to be an inverse relationship between CAD symptoms and CACS.

Various studies have shown that there is strong correlation between CAC and age and gender. PREDICT Study Group brought up a significant correlation between advanced age and male gender and CACS [15-17] in a vast series. In this study, we observed that CAC increases as the age advances and it is more prevalent in male patients. Coronary artery calcification was detected in $13.3 \%$ of the cases in 40 to 49 age group, in $38.1 \%$ of the cases in 50 to 59 age group, and in $40 \%$ of the cases at the age of 60 and above. Furthermore, $42.9 \%$ of cases with CACS $>0$ were male and $22.2 \%$ were female. This shows that $\mathrm{CAC}$ bears close relation with age and gender. These findings demonstrate a concordance with the information presented in the literature. Obesity and hypertension are a part of metabolic syndrome. According to definitions by NCEP and WHO, metabolic syndrome contains criteria for both blood pressure and central body fat and it is among the risk factors playing a role in the development of CAD. In a study that included asymptomatic type 2 diabetic patients, a significant relation was established between waist to hip rate and CAC [16].

In a study by PREDICT Study Group conducted with type 2 diabetics, a statistically significant relation was established between body mass index and waist to hip rate with CAC [17]. A study by Arad et al. [18] demonstrated a positive correlation between CAC and abdominal fat tissue in patients with no CAD. In a study in which Mazzone et al. [19] compared the relationship between anthropometric measurements and CAC, a significant relation between total abdominal fat tissue, visceral fat tissue, waist to hip rate, and CAC was observed, however, there wasn't any significant relationship between body mass index and waist circumference and CAC. In this study, waist circumference and body mass index among anthropometric measurements was utilized, which are also the criteria of metabolic syndrome. While a significant relation was established between waistline and CAC $(\mathrm{p}<0.05)$, no significant relation was observed between body mass index and CAC. The reason for this insignificant relationship between body mass index and CAC could be that the body mass index of individuals included in the study was similar (29.79 \pm 4.36 ). Nevertheless, significant correlation between waist circumference and CAC could be related with fat tissue hormone leptin; since in obese individuals, the increased leptin concentration is correlated with waist circumference and visceral fat tissue measured by computerized tomography. Furthermore, leptin concentration is related with insulin resistance in type 2 diabetics and is a characteristic of metabolic syndrome. The fact that CAC has correlation with increased waistline in type 2 diabetics may occur due to the direct effect of leptin on vascular calcification. As indicated in the 7th report of Joint National Committee (JNC), having a lower blood pressure value than $130 / 80 \mathrm{mmHg}$ is required for individuals with diabetes or kidney diseases [20]. 
In two separate studies, Elkeles et al. [16, 21] studied the relation between systolic blood pressure (SBP) and CAC and found a positive correlation between these two variables. Mazzone et al. [19] demonstrated that each $10 \mathrm{mmHg}$ increase in SBP of diabetes patients causes a $67 \%$ gain in CAC. In our study, a statistically significant relation was observed between SBP and CAC, meaning that the SBPs of patients with CACS $>0$ was statistically higher when compared with $\mathrm{CACS}=0$ individuals. Systolic blood pressure is a component of metabolic syndrome and seems to be related with CAC just like the waist circumference. Our data correspond prior studies in the literature at this point. Increase in TG and decrease in HDL in diabetic patients accelerates atherosclerosis. This form of dyslipidemia seen in type 2 DM generally exists even before diabetes occurs. Elkeles et al. [16] conducted a study with type 2 diabetic patients, did not find significant relation between basal CACS and any lipid parameter (TG, LDL, TC, HDL). However, they found a significant correlation between the use of statins and CAC. In that study, same authors followed diabetic patients for 4 years by means of EBCT and CACS. They did not establish a statistically significant correlation between CAC progression and changes in any lipid profile (LDL, TG and HDL). However, they found a positive correlation between the use of statins and CAC progression. They emphasized that the CAC progression was higher with the use of statins, because statin use was associated with the severity of already-present atherosclerosis, and they suggested that the CAC progression is therefore higher in individuals using statins [15]. MESA study demonstrated that lipid levels are correlated with basal CACS but not related with CACS progression [22]. In this study, while there was a significant relation between CACS and LDL, TG and TC, no significant correlation was observed between CACS and HDL. However, mean serum HDL level $(37.13 \pm 5.72)$ of individuals with CACS $>0$ was lower than the mean serum HDL level $(40.08 \pm 14.04)$ of individuals with $\mathrm{CACS}=0$. Twenty percent of the patients included in this study were receiving lipid-lowering treatment. In one of the studies conducted by PREDICT Study Group $45 \%$ of patients were taking lipid-lowering treatment, and in another, $35 \%$ of the patients were receiving lipid-lowering treatment in their later follow-ups $[15,16]$. The fact that less patients were taking lipid-lowering treatment (20\% of population) may explain the correlation between CAC and TG, LDL and TC. Mazzone et al. [19] studied the correlation between inflammatory reagents (hsCRP, ICAM-1, VCAM-1, phospholipase A2) and metabolic factors (HbA1c, HOMA-IR, diabetes duration) with CAC. They did not report a statistically significant correlation between inflammatory reagents and metabolic factors with CAC. Similarly, neither inflammatory reagents (hs-CRP) nor metabolic factors (HbA1c, Ca, P, PTH and diabetes duration) were correlated with CAC in our study.

In conclusion, our data shows a correlation between CAC and waist circumference, systolic blood pressure, TG, TC and LDL in patients with type 2 DM. It seems that CACS appears to be an important accompany of other major cardiovascular markers. We think that type $2 \mathrm{DM}$ cases with CACS $>0$ deserve a more careful follow up in the long run in terms of CAD, and a more intensive treatment is necessary.

\section{References}

1. Merz CN, Buse BJ, Tuncer D, Twillman GB. Physician attitudes and practices and patient awareness of the cardivasculary complications of diabetes. J Am Coll Cardiol 2002; 40:1877-81.

2. Haffner SM, Lehto S, Ronnemaa T, Pyrola K, Laakso M. Mortality from coronary heart disease in subject with type 2 diabetes and in nondiabetic subject with without prior myocardial infarction. N Eng J Med 1998; 339: 229-34.

3. Anand DV, Lim E, Darko D, Bassett P, Hopkins D, Lipkin D, Corder R, Lahiri A. Determinants of progression of coronary artery calcification in type 2 diabetes role of glycemic control and inflammatory/vascular calcification markers. J Am Coll Cardiol 2007; 50: 2218-25.

4. Chambless L, Keil U, Dobson A, Mähönen M, Kuulasmaa K, Rajakangas AM, 
Löwel H, Tunstall-Pedoe H. Population versus clinical view of case fatality from acute coronary heart disease: results from the WHO MONICA Project 19851990. Multinational MONItoring of Trends and Determinants in CArdiovascular Disease. Circulation 1997; 96: 3849-59.

5. Janowitz WR, Agatston AS, Kaplan G, Viamonte M Jr. Differences in prevalence and extent of coronary calcium detected by ultrafast computed tomography in asymptomatic men and women. Am J Cardiol 1993; 72: 247-54.

6. Yenigün M. Kardiyovasküler Diabet. Ed: Yenigün M, Altuntaş Y, Her yönüyle diabetes mellitus. 2. bask1, İstanbul, Nobel Tip Kitabevleri 2001; 639-97.

7. Çakır N. Diabetes Mellitus ve Ateroskleroz İlişkisi. Turkiye Klinikleri J Int Med Sci 2007, 3: 61-7.

8. Agatston AS, Janowitz WR, Hildner FJ, Zusmer NR, Viamonte M Jr, Detrano R. Quantification of coronary artery calcium using ultrafast computed tomography. J Am Coll Cardiol 1990; 15: 827-32.

9. Yoshida M, Takamatsu J, Yoshida S, Tanaka K, Takeda K, Higashi H, Kitaoka $\mathrm{H}$, Ohsawa N. Scores of coronary calcification determined by electron beam computed tomography are closely related to the extent of diabetes-specific complications. Horm Metab Res 1999; 31: 558-63.

10. Schurgin S, Rich S, Mazzone T. Increased prevalence of significant coronary artery calcification in patients with diabetes. Diabetes Care 2001; 24: 335-8.

11. Cerqueira MD. EBCT: Identifying the "Vulnerable Patient" CME. 51 st Scientific Session of the American Collage of Cardiology Atlanta, Georgeia 2002; 3: 17-20.

12. Mielke CH, Shields JP, Broemeling LD. Coronary artery calcium, coronary artery disease, and diabetes. Diabetes Res Clin Pract 2001; 53: 55-61.

13. Khaleeli E, Peters SR, Bobrowsky K, Oudiz RJ, Ko JY, Budoff MJ. Diabetes and the associated incidence of subclinical atherosclerosis and coronary artery disease: implications for management. Am Heart J 2001; 141: 637-44.

14. Raggi P, Shaw JL, Berman SD, MD, Callister TQ. Prognostic value of coronary artery calcium screening in subjects with and without diabetes. J Am Coll Cardiol 2004; 43: 1663-9.

15. Elkeles RS, Godsland IF, Rubens MB, Feher MD, Nugara F, Flather MD. The progress of coronary heart disease in Type 2 diabetes as measured by coronary calcium score from electron beam computed tomography (EBCT): The PREDICT study. Atherosclerosis 2008; 197: 777-83.

16. Elkeles RS, Feher MD, Flather MD, Godsland IF, Nugara F, Richmond W, Rubens MB, Wang D. For the PREDICT Study Group. The association of coronary calcium score and conventional cardiovascular risk factors in Type 2 diabetic subjects asymptomatic for coronary heart disease (The PREDICT Study). Diabet Med 2004; 21: 1129-34.

17. Godsland IF, Elkeles RS, Feher MD, Nugara F, Rubens MB, Richmond W, Khan M, Donovan J, Anyaoku V, Flather MD. For the PREDICT Study Group. Coronary calcification, homocysteine, C-reactive protein and the metabolic syndrome in Type 2 diabetes: The Prospective Evaluation of Diabetic Ischaemic Heart Disease by Coronary Tomography (PREDICT) Study. Diabet Med 2006; 23: 1192-200.

18. Arad Y, Newstein D, Cadet F, Roth M, Guerci AD. Association of multiple risk factors and insulin resistance with increased prevalence of asymptomatic coronary artery disease by an electron beam computed tomographic study. Arterioscler Thromb Vasc Biol 2001; 21: 2051-8.

19. Mazzone T, Meyer PM, Kondos GT, Davidson MH, Feinstein SB, D'Agostino RB, Perez A, Haffner SM. Relationship of traditional and nontraditional cardiovascular risk factors to coronary artery calcium in type 2 diabetes. Diabetes 2007; 56: 849-55.

20. Kozan Ö, Savaş İZ. Hangisi daha önemli? Diastolik hipertansiyon, sistolik hipertansiyon. Kardiyoloji ve aktüalite dergisi 2003; 2: 6-11. 
21. Elkeles RS, Godsland IF, Feher MD, Rubens DM, Roughton M, Nugara F, Humphries SE, Richmond W, Flather M. For the PREDICT Study Group. Coronary calcium measurement improves prediction of cardiovascular events in asymptomatic patients with type 2 diabetes: the PREDICT study. Eur Heart J 2008; 29: 2244-51.

22. Kronmal RA, McClelland RL, Detrano R, Shea S, Lima JA, Cushman M, Bild DE, Burke GL. Risk factors for the progression of coronary artery calcification in asymptomatic subjects: results from the Multi-Ethnic Study of Atherosclerosis (MESA). Circulation 2007; 115: 2722-30. 